\title{
9. GUEMBELITRIA AFF. STAVENSIS BANDY, A PALEOOCEANOGRAPHIC MARKER OF THE INITIATION OF THE CIRCUM-ANTARCTIC CURRENT AND THE OPENING OF THE DRAKE PASSAGE
}

\author{
D. Graham Jenkins, Department of Geology, University College of Wales, Aberystwyth, Wales
}

\begin{abstract}
The paleooceanographic and stratigraphic distribution of Guembelitria aff. stavensis Bandy in oceanic sediments around Antarctica provides evidence of the initiation of the circum-Antarctic Current including the oldest date for the opening of the Drake Passage in the lower part of the upper Oligocene $G$. $(G$.) euapertura Zone. Paleontological events are correlated with $\mathrm{K} / \mathrm{Ar}$ dates and it is postulated that the Drake Passage was open to the flow of oceanic water which supported plankton, at about 28 m.y.B.P.
\end{abstract}

\section{INTRODUCTION}

Guembelitria aff. stavensis Bandy (Plate 1, Figures 18) lived in the gulf between Australia and Antarctica from the late Eocene through to the lower part of the upper Oligocene (Ludbrook and Lindsay, 1969; Lindsay, 1969). With the final separation of the two continents at the eastern hinge of the austral gulf at the South Tasman Rise, $G$. aff. stavensis spread out eastwards into the south-western Pacific and lived only briefly (Figures 1,2) as previously reported by Jenkins (1974). The paleogeographic distribution of $G$. aff. stavensis in the southwestern Pacific and its migration around Antarctica to Site 360 of DSDP Leg 40 (latitude $35^{\circ} 50^{\prime} \mathrm{S}$; longitude $18^{\circ} 05^{\prime} \mathrm{E}$ ) provides the first fossil evidence of the separation of South America from Antarctica and the initial opening of the Drake Passage. The spread of $G$. aff. stavensis in the plankton around Antarctica marks the initiation of the circumAntarctic Current, but it was probably some time later that the current assumed its major role as one of the largest oceanic currents (Kennett et al., 1975).

\section{SYSTEMATICS}

Following the work of Ludbrook and Lindsay (1969) the writer placed the Oligocene specimens of Guembelitria in G. stavensis Bandy (Jenkins, 1974) which had originally been described from the middle Eocene of Little Stave Creek, Alabama, USA. A topotype sample of $G$. stavensis has been obtained from the Department of Geology, Los Angeles, and a slide of the holotype plus six paratypes has been kindly loaned for examination by Dr. Alan Horowitz, Indiana University.

Specimens of the topotype sample are very small ranging in size from 0.19 to $0.09 \mathrm{~mm}$ in length, but the holotype is slightly longer at $0.21 \mathrm{~mm}$ in length.

Scanning electron microscope examination shows that specimens from DSDP Site 360 (Sample 29-2, 73$75 \mathrm{~cm}$ ) (Plate 1, Figures 1-8) have distinct supplementary apertures which do not occur in the topotype

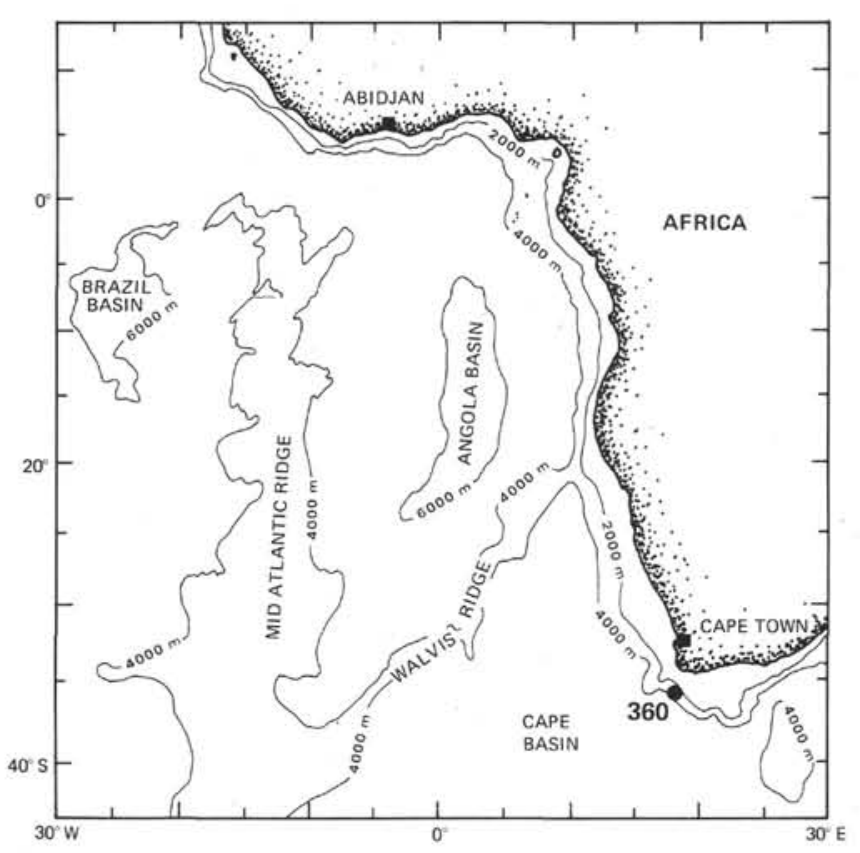

Figure 1. Location of Leg 40, Site 360.

specimens of G. stavensis (Plate I, Figures 9-13). Also, the wall structure appears to be different (Plate 1, Figures 8, 13).

At this stage, it is safe to conclude that the specimens of $G$. stavensis from the middle Eocene of Alabama appear to be morphologically different from those obtained from the upper Oligocene of Site 360 and are consequently referred to as $G$. aff. stavensis. Further research is being undertaken into specimens of $G$. aff. stavensis from around Antarctica. This may result in the need for a new name for the southern species.

\section{BIOSTRATIGRAPHY}

The stratigraphic range of $G$. aff. stavensis has been previously plotted against the range of Chiloguembelina cubensis (Palmer) (Jenkins, 1974; see also Figure 3). 


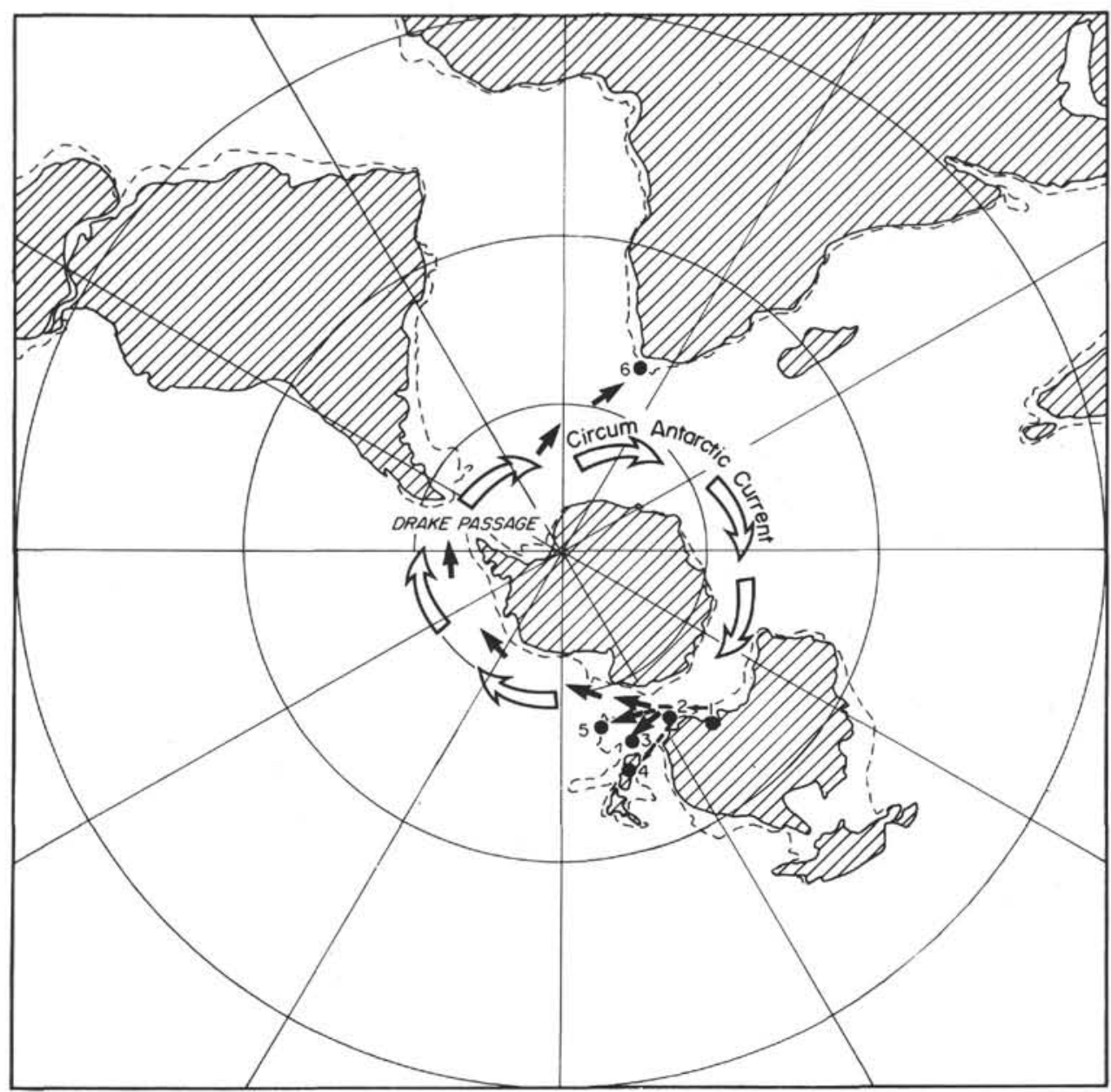

Figure 2. Map of the distribution of continents and oceans in the Southern Hemisphere and a plot of six localities and postulated migration of G. aff. stavensis in the Oligocene G. (G.) euapertura Zone. Map is after Smith and Briden (in press), but it is possible that the Drake Passage was much narrower at this stage in the Oligocene.

Once $G$. aff. stavensis migrated from the gulf between Antarctica and Australia, it lived only briefly in the lower part of the $G$. (G.) euapertura Zone. It became extinct before the extinction of $C$. cubensis, west of Tasmania (DSDP Site 282), on the western edge of the Campbell Plateau (DSDP Site 277) and on the east coast of the South Island of New Zealand. But at DSDP Site 360, in the southeastern Atlantic, $G$. aff. stavensis briefly survived the extinction of $C$. cubensis. Assuming that the extinction of $C$. cubensis was a synchronous event in the areas under investigation, then the later extinction of $G$. aff. stavensis at Site 360 could be due to the longer migration time it took to reach the site; it could also mean that the opening of Drake Passage was slightly later than the parting of the South Tasman Rise from Antarctica.

Confirmation of the correlation of the brief stratigraphic range of $G$. aff. stavensis in the areas beyond South Australia has come from a further examination of the planktonic foraminifer fauna. The writer described and illustrated the direct phyletic evolution of Globorotalia munda Jenkins into Globigerina juvenilis Bolli in the Earthquakes Section of the Kokoamu
Greensand, New Zealand (Jenkins, 1966). The evolutionary change in morphology occurs relatively rapidly, and at DSDP Sites 277 and 282 (Jenkins, 1975) and at Site 360, $G$. aff. stavensis occurs only during this transition of $G$. munda into $G$. juvenilis. Also, $G$. aff. stavensis appears to occur at the same level in Sample S127/f 403 from New Zealand.

\section{PALEOECOLOGY}

$G$. aff. stavensis migrated further north in the upper Oligocene in the southeastern Atlantic than in the New Zealand area. It was found at Site 360 (latitude $35^{\circ} 50^{\prime} \mathrm{S}$ ), but is not present at Site 362 (latitude $19^{\circ} 45^{\prime} \mathrm{S}$ ) in the Atlantic. In New Zealand $G$. aff. stavensis migrated only into the southern half of the South Island (latitude $44^{\circ} 30.6^{\prime} \mathrm{S}$ ). It therefore seems probable that the oceanic water suitable for the survival of $G$. aff. stavensis spread further north along the coast of southwest Africa during the upper Oligocene than it did near New Zealand. It is further speculated that $G$. aff. stavensis may have preferred the cooler southern water. 


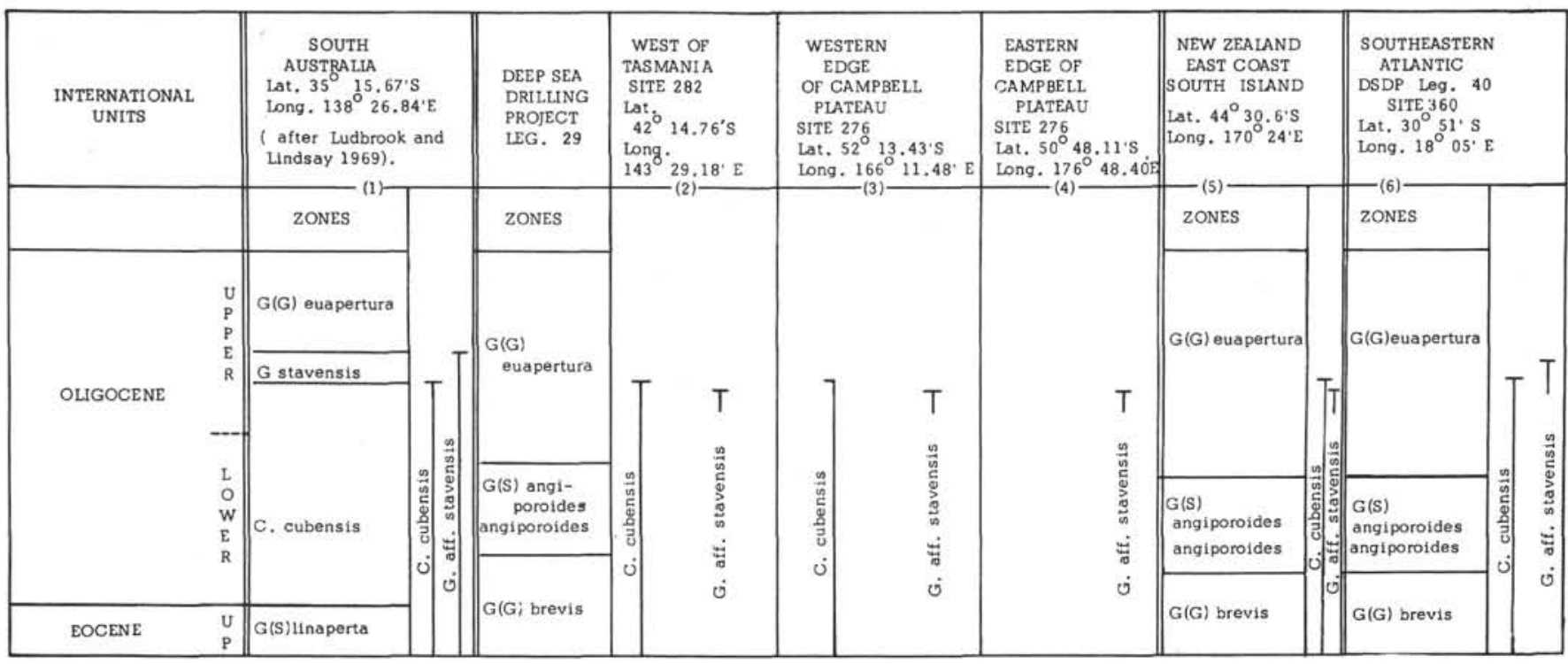

Figure 3. Stratigraphic records of G. aff. stavensis in South Australia, three sites of DSDP Leg 29, one in New Zealand and one of DSDP Leg 40.

\section{CIRCUM-ANTARCTIC CURRENT}

Kennett et al. $(1973,1975)$ suggested that the circumAntarctic Current started during the late Oligocene, based on an interpretation of a late Paleogene regional unconformity in the Tasman and Coral seas. Frakes and Kemp (1973) postulated that the Drake Passage opened by the middle Oligocene, and Baker et al. (1974) suggested that it was open by the middle-upper Miocene. Jenkins (1974) provided evidence that the paleogeographic and stratigraphic distribution of $G$. aff. stavensis was a key to the paleontological dating of the initiation of the current. Its further presence in the lower part of the $G$. (G.) euapertura Zone at Site 360 (Samples 29-2, 73-75 cm and 30-1, 97-99 cm) is additional evidence of its spread around Antarctica in the proto circum-Antarctic Current.

\section{DATING THE EVENT}

Berggren (1972) termed the extinction of C. cubensis as the "Chiloguembelina extinction Datum." This he placed in about the middle of the Oligocene Globigerina angulisuturalis/Globorotalia (Turborotalia) opima opima Zone and correlated it with the type Chattian. Berggren (1972) recorded K/Ar dates on the type Chattian of the North German Basin with a range of 28.8-31.2 \pm 1.5 m.y.B.P. Abele and Page (1974) reported a date of 26.527 m.y. on a basalt in Victoria, Australia. This basalt erupted somewhat later than the locally recorded extinction of $C$. cubensis, supporting Berggren's dating of the extinction of $C$. cubensis at $28 \mathrm{~m} . \mathrm{y}$

\section{CONCLUSIONS}

The distribution of $G$. aff. stavensis in DSDP drill sites and elsewhere indicates that it migrated eastwards from the area of South Australia within the plankton of the proto circum-Antarctic Current, then around Antarctica, and eventually through the Drake Passage, reaching the southeastern Atlantic Site 360 about 28 million years ago.
More sites need to be drilled into suitable Oligocene $G$. (G.) euapertura Zone sediments between the Campbell Plateau south of New Zealand, the Drake Passage and Site 360 in the southeastern Atlantic to plot the paleooceanographic migration of $G$. aff. stavensis around Antarctica.

\section{ACKNOWLEDGMENTS}

My thanks are due to: Professor H.M. Bolli for providing me with Leg 40 samples and facilities at Zurich where the SEM photographs were taken by Mr. H. Franz, which were later printed by Mr. H. Williams at Aberystwyth; Dr. A.G. Smith and Dr. J.C. Briden and Cambridge University Press for permission to reproduce the map for Figure 2 to be published in "Mesozoic and Cenozoic Paleocontinental Maps." Mr. M. Lindsay, Mr. D. Taylor, and Dr. N. de B. Hornibrook, for specimens of $G$. aff. stavensis; Department of Geology, Los Angeles, for a topotype sample of $G$. stavensis Bandy; and Dr. A. Horowitz, Indiana University, for a loan of the G. stavensis holotype.

\section{REFERENCES}

Abele, C. and Page, R.W., 1974. Stratigraphic and isotopic ages of Tertiary basalts of Maude and Aireys Inlet, Victoria, Australia: Roy. Soc. Vict. Proc., v. 86, p. 143.

Baker, P.F., Dalziel, I.W.D., et al., 1974. Southwestern Atlantic: Geotimes, v. 19, p. 16.

Berggren, W.A., 1972. A Cenozoic time-scale-some implications for regional geology and paleobiogeography: Lethaia, v. 5, p. 195.

Frakes, L.A. and Kemp, E.M., 1973. Paleogene continental positions and evolution of climate. In Tarling, D.H. and Runcorn, S.K. (Eds.), Implications of Continental Drift to the earth sciences: v. 1, p. 539.

Jenkins, D.G., 1966. Planktonic foraminiferal zones and new taxa from the Danian to lower Miocene of New Zealand: New Zealand J. Geol. Geophys., v. 8, p. 1088.

1974. Initiation of the proto circum-Antarctic current: Nature, v. 252, p. 371.

1975. Cenozoic planktonic foraminiferal biostratigraphy of the southwestern Pacific and Tasman Sea-DSDP Leg 29. In Kennett, J.P., Houtz, R.E., et al., Initial Reports of the Deep Sea Drilling Project, Volume 
29: Washington (U.S. Government Printing Office), p. 449.

Kennett, J.P. et al., 1973. Deep-sea drilling in the roaring 40s: Geotimes, v. 18 , p. 14

Kennett, J.P., Houtz, R.E., et al., 1975. Cenozoic paleooceanography in the Southwest Pacific Ocean, Antarctic Glaciation, and the development of circum-Antarctic current, DSDP, Leg 29. In Kennett, J.P., Houtz, R.E., et al., Initial Reports of the Deep Sea Drilling Project, Volume 29: Washington (U.S. Government Printing Office), p. 1155.
Lindsay, J.M., 1969. Foraminifera and stratigraphy of the type section of Port Willunga Beds, Aldinga Bay: South Australia Trans., v. 91, p. 93.

Ludbrook, N.H. and Lindsay, J.M., 1969. Tertiary foraminiferal zones in South Australia. Internat. Conf. Plankt. Microfossils 1st Geneva (1967), Proc., v. 2, p. 366 .

Smith, A.G. and Briden, J.C., in press. Mesozoic and Cenozoic paleocontinental maps: Cambridge (Cambridge University Press). 



\section{PLATE 1}

Figures 1-5 Guembelitria aff. stavensis Bandy. Sample 360-292, $73-75 \mathrm{~cm}$, upper Oligocene. $G$. (G.) euapertura Zone.

1. Side view, $\times 250$.

2. Aperture, $\times 1000$.

3. Aperture enlarged to show lip, $\times 2500$.

4. Secondary aperture, $\times 1000$.

5 . Two secondary apertures, $\times 1000$.

Figures 6-8 Guembelitria aff. stavensis Bandy. Sample 360-292, 73-75 cm, upper Oligocene. G. (G.) euapertura Zone.

6. Side view, $\times 250$.

7. Aperture, $\times 1000$.

8. Wall structure, $\times 2500$.

Figures 9-11 Guembilitria stavensis Bandy. Little Stave Creek, Alabama, USA Locality 10, topotype sample, middle Eocene.

9. Side view, $\times 250$.

10. Aperture, $\times 1000$.

11. Wall structure, $\times 2500$.

Figures 12,13 Guembelitria stavensis Bandy. Little Stave Creek, Alabama, USA Locality 10, topotype sample, middle Eocene.

12. Side view, $\times 250$.

13. Aperture, $\times 1000$. 
PLATE 1
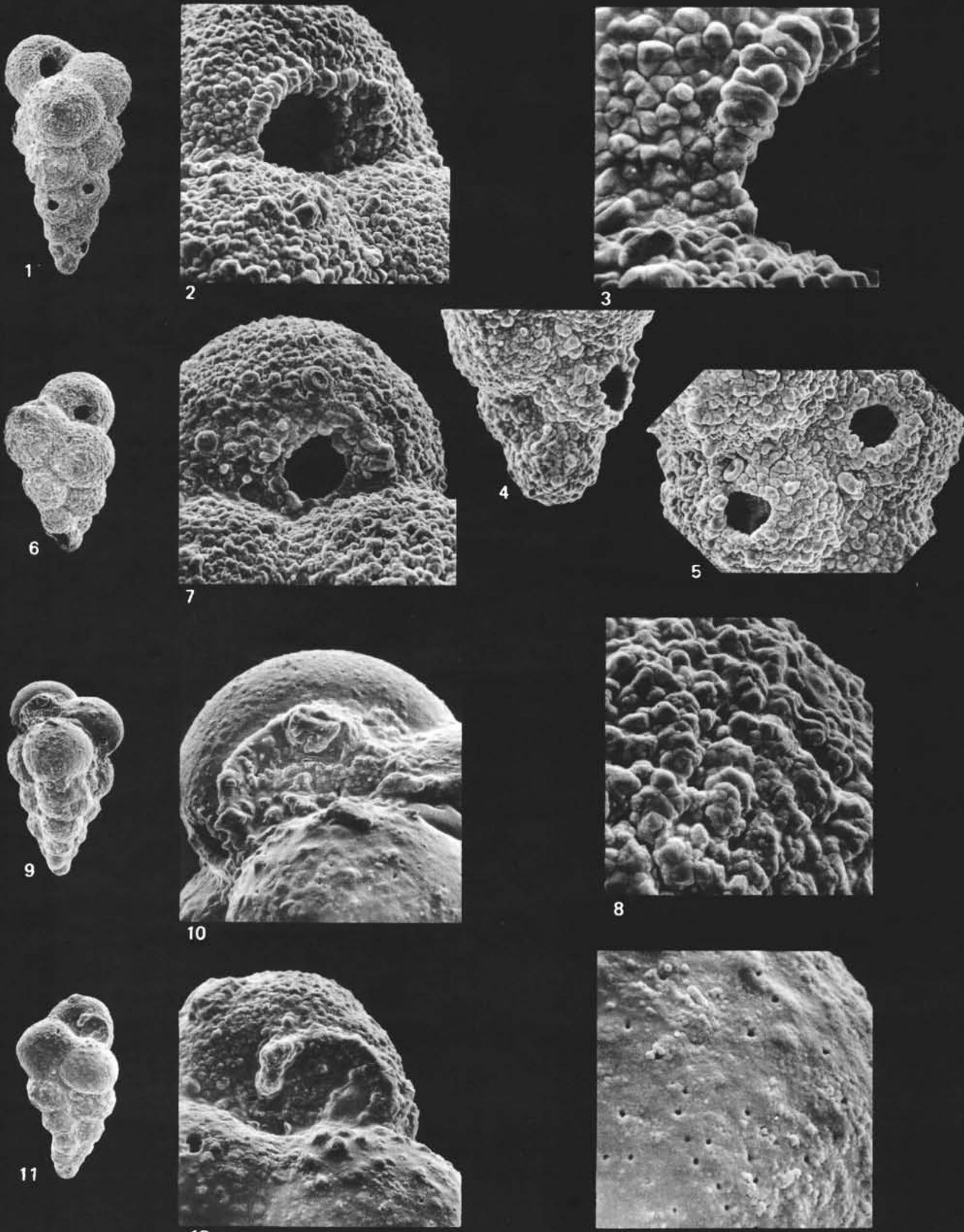